\title{
Tree Growth Prediction in Relation to Simple Set of Site Quality Indicators for Six Native Tree Species in the Philippines
}

\author{
F. Santos Martin, B. Lusiana, and M. van Noordwijk \\ World Agroforestry Centre South-East Asia (ICRAF-SEA), P.O. Box 161, Bogor 16001, Indonesia \\ Correspondence should be addressed to F. Santos Martin, santosmartinfer@gmail.com \\ Received 14 May 2010; Accepted 2 August 2010 \\ Academic Editor: Guofan Shao
}

Copyright () 2010 F. Santos Martin et al. This is an open access article distributed under the Creative Commons Attribution License, which permits unrestricted use, distribution, and reproduction in any medium, provided the original work is properly cited.

\begin{abstract}
The gain in precision to explain the variation on tree growth performance as a function of a set of site indicators was analysed in a stepwise form, increasing its complexity and costs. Six native timber tree species were commonly found on farmer's fields and planted under different types of agroforestry systems. Localization of trees to be used for measurement was achieved through individual interviews to assess timing of introduction of trees. Results proved that native tree species planted on farmers' fields have similar growth rate other exotic timber species as Swietenia macrophylla that are widely spread in the Philippines. Nevertheless, the large fraction of the variation in tree performance that could not be explained by the biophysical site indicators measured implies that farmers take considerable risk in planting trees on the basis of current "scientific" knowledge. The complement of "site characteristics" is probably "management", and the low determination of tree growth by site properties may in fact be good news for the farmers.
\end{abstract}

\section{Introduction}

During the past 30 years, large areas have been "reforested" in different areas of the Philippine uplands [1]. However, survival rate was very low, and slow growth of planting stocks was registered all along the country [2]. This was attributed to the unfavourable growing condition of the site and to failure in selection of appropriate species [3]. Matching tree species to the biophysical characteristics of a site is necessary but not sufficient to ensure adoption. Trees also have to be compatible with views, experiences, traditions, and economic capacities of the farmers [4].

Usually tree-site matching is approached from two different perspectives: trees or sites [5]. The trees' perspective will have the objective to develop suitable site maps for each tree species given its provenance. From the site perspective, efforts will try to list the "best bet" tree species for each site [6]. But from the farmer's point of view the choice also involves comparison with other options and the main question addressed from this perspective will be how can I judge whether a given tree and site combination will be productive?, or how can I evaluate cost-benefit of modified choice based on better (and more expensive) information? In this study efforts have been focused on the third perspective as a combination of the traditional tree and site approaches (Table 1).

Despite the importance of such site-species matching, species selection by farmers appears to be based on other factors [7]. Firstly, farmers strongly favour a species from which high returns have been obtained in the past. Secondly, farmers almost invariably choose a species for which planting material is low in cost and readily available. As a result, most common species found in upland farms in the Philippines are fast growing exotic species as Gmelina (Gmelina arborea), Mangium (Acacia mangium), Mahogany (Swietenia macrophylla), and Falcata (Paraserianthes falcataria). However, new initiatives of agroforestry development are trying to integrate native tree species into agricultural systems because increasing the quality, number, and diversity of domesticated trees should enhance agroforestry capacity to fulfill its ultimate potential as a way to alleviate poverty and to mitigate deforestation and land depletion [8].

According to Roshetko and Evans [9] to thoroughly assess the potential of promising and preferred native tree 
TABLE 1: Tree-site matching from three different methodological perspectives.

\begin{tabular}{llll}
\hline $\begin{array}{l}\text { Perspective } \\
\text { (1) Tree: }\end{array}$ & Step 1 & Step 2 & Step 3 \\
$\begin{array}{l}\text { What are suitable sites for } \\
\text { this tree species (given its } \\
\text { provenance)? }\end{array}$ & $\begin{array}{l}\text { Calculate performance } \\
\text { relative to "reference" }\end{array}$ & $\begin{array}{l}\text { Identify "growth retarding" } \\
\text { factors: landscape position, } \\
\text { soil type, soil physics, soil } \\
\text { chemical factors }\end{array}$ & $\begin{array}{l}\text { Map relative suitability } \\
\text { based on combined model } \\
\text { for each tree species }\end{array}$ \\
\hline $\begin{array}{l}\text { (2) Site: } \\
\begin{array}{l}\text { What are the best tree } \\
\text { species for this site? }\end{array}\end{array}$ & $\begin{array}{l}\text { Derive efficient site } \\
\text { typology }\end{array}$ & $\begin{array}{l}\text { Combine relative } \\
\text { performance per tree } \\
\text { species with expected value } \\
\text { for the farmer }\end{array}$ & $\begin{array}{l}\text { List the "best bet" tree } \\
\text { species for each site }\end{array}$ \\
$\begin{array}{l}\text { (3) Farmer: } \\
\begin{array}{l}\text { Based on what information } \\
\text { can I judge whether a given } \\
\text { tree \& site combination will } \\
\text { be productive? }\end{array}\end{array}$ & $\begin{array}{l}\text { In Tree-Step 2: calculate } \\
\text { stepwise adjusted } \mathrm{R}^{2} \text { : what } \\
\text { gain in precision can be } \\
\text { obtained with more } \\
\text { complete information }\end{array}$ & $\begin{array}{l}\text { Compare costs of obtaining } \\
\text { various site indicators to } \\
\text { the expected gain in } \\
\text { predictive power of } \\
\text { performance }\end{array}$ & $\begin{array}{l}\text { Evaluate cost-benefit of } \\
\text { modified choice based on } \\
\text { better information }\end{array}$ \\
\hline
\end{tabular}

species for on-farm domestication should first take into consideration plant spacing and pattern, management practice and suitability or growth performance in varying site conditions. The function, patterns, and management systems of smallholder timber plantations are markedly different from those found in natural forest, government-sponsored reforestation, and plantation forestry [7]. To better serve these functions, trees may be incorporated in various densities and arrangements in existing farm niches (e.g., cropping areas, homestead). This set of interrelated decisions of a tree growing practice will eventually define the attributes of the appropriate tree species to be selected for on-farm planting to perform the intended function [10].

Nowadays a number of databases exists that classify trees by their broad climatic requirements and types of use. This information is generally not sufficiently precise to guide local choice of species, where no systematic testing of provenances has been carried out yet [9]. A detailed landscape and soil characterization will help identify site-specific tree and soil attributes. For example, in undulating landscapes, the tops and crests of ridges, the mid-slope position and the valley bottoms offer very different soil fertility and water supply conditions [11]. This site characterization will thus provide a valuable database for assessing the suitability of specific tree species for such agroforestry systems.

Therefore, the main objective of this study is to provide the necessary basis for smallholder farmers to test selected native trees by site matching to better recognize and utilize agricultural landscape niches. Specifically this study will (i) evaluate gain in tree growth prediction in relation to a simple set of site quality indicators, and (ii) evaluate costs of obtaining various site indicators to the expected gain in predictive power of tree performance.

\section{Methodology}

2.1. Study Area. This study is part of a broader assessment of the use of native timber trees in upland farming, which included an analysis of farmer management practices, aspects of tree-site matching and economic analysis of agroforestry systems [12]. Leyte province (Central Philippines) was selected because it is representative of upland environments that are intensively cultivated, vastly degraded and where farmers have started to plant native timber trees as a strategy for livelihoods as well as recovering degraded uplands [13, 14]. The village of Manlawaan was selected as the study site because it is one of the most remote and poorest communities and was one of the early sites of the Operation Land Transfer of the agrarian reform program from the Philippine government [15].

2.2. Searching for Planted Native Trees. The starting point of the study was the location and measurement of native trees planted at different farmers' sites located across Manlawaan's agricultural landscape. Diameter at breast height (DBH) and total height were measured during field visits. A total of sixteen farmers who had planted native trees species on their farms in the past were involved in the study. Six native timber tree species were commonly found on farmer's fields and planted under different types of agroforestry systems (Table 2). Localization of trees to be used for measurement was achieved through individual interviews to assess timing of introduction of trees.

2.3. Soils Sampling. A combined analysis of soil physical and chemical properties were performed on farmers' collaborators farms only for the top layer as it is the most dynamic layer [16]. Soil samples were collected from the three parts of every farm that included the upper, middle, and lower slope. Soil samples were taken at $20 \mathrm{~cm}$ depth without litter for at least one kilogram per hole and placed in separate plastic cellophane bags and properly labelled. Samples collected from the three part of the farm were combined to derive one composite sample that represents the whole parcel/farm. Air dry composite soil samples were sieved at $2 \mathrm{~mm}$. Sieved soil samples were analyzed at the Department of Agronomy and 
TABLE 2: Total number of trees measured for each species found in Manlawan.

\begin{tabular}{lllc}
\hline Scientific Name & Common Name & Family & Number \\
\hline Shorea contorta Vid. & White lauan & Dipterocarpaceae & 132 \\
Vitex parviflora Juss. & Molave & Verbenaceae & 143 \\
Pterocarpus indicus Willd. & Narra & Fabaceae & 127 \\
Artocarpus heterophyllus Lam. & Nangka & Moraceae & 115 \\
Dracontomelon dao Blanco. & Dao & Anacardiaceae & 85 \\
Afzelia rhomboidea Blanco. & Tindalo & Caesalpiniaceae & 72 \\
\hline
\end{tabular}

Soil Science Laboratory in Leyte State University (LSU) using their standard procedures for the following parameters: $\mathrm{pH}$ (water), organic matter (Wackley Balck), total nitrogen (Kjeldahl), extractable phosphorus (Olsen), exchangeable potassium, soil texture (sand, silt and clay content), and bulk density. Additional details of site characteristics included GPS location, parcel size, slope details, orientation, and soil sampling.

2.4. Growth Reference Functions (GRFs). Anybody who wishes to use any of the available growth equations for a new situation is faced with a difficult choice among the various types of equations. The most commonly used functions are polynomials and power models [17]. Although polynomials (usually quadratic or cubic equations) may provide good fits with the measurement range, their inherent shape is nonnatural and extrapolation outside of the range of the original model calibration is risky [18]. The exponential function form is widely found within agroforestry [19] and has some attractive interpretations for scaling. Based on tree data collected from farmers sites an exponential reference growth function was derived for each tree species found:

$$
D=a e^{b t}
$$

where $a$ and $b$ factors were determined by logarithmic regression of $D$ (Diameter) and $t$ (age) for each tree species (Figure 1). Thus, trees which are below the reference growth curves grow slower than the average. The delay in performance may be due to many factors (i.e., site conditions, management, germplasm, errors of measurement) but in this analysis only the following site components were quantified: landscape position, soil type, soil physical properties, and soil chemical parameters.

Above analysis could be done either by "relative size per age" (relative to the Y-axis) or by "relative apparent growth rate" (relative to the $\mathrm{X}$-axis). If the reference growth curve is nonlinear (and/or not passing through the origin) these two approaches give different results. Following the methodological approach used by Lusiana and van Noordwijk [5], the "Growth Retardation Factor" (GRF) was defined as the relation between the actual and expected age of one tree given its growth performance.

Mathematically, the GRF was defined as

$$
\mathrm{GRF}=\log \left(\frac{t_{\text {observed }}}{t_{\text {expected }}}\right),
$$

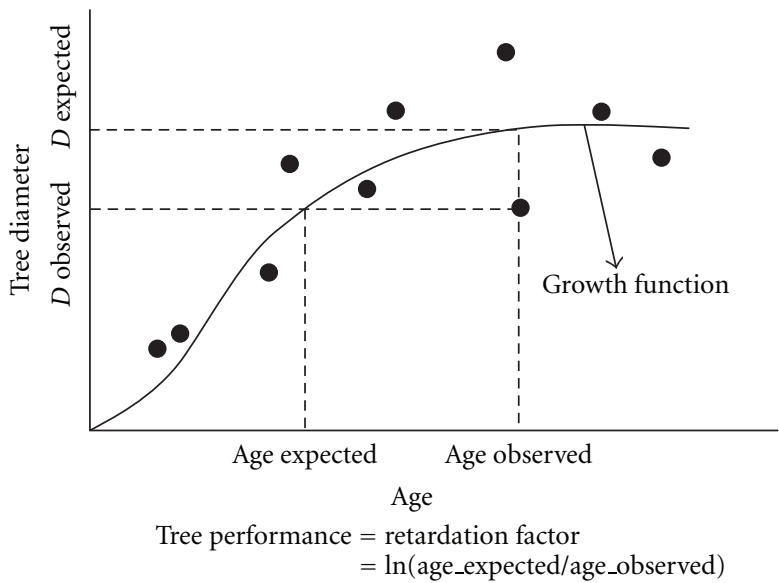

FIGURE 1: Representation of reference growth function and calculation of Growth Retardation Factor (GRF).

where the $t_{\text {expected }}$ was calculated as

$$
t_{\text {expected }}=\frac{\left(\log \left(D_{\text {observed }} / a\right)\right)}{b}
$$

with $a$ and $b$ derived for the total data set for each tree species.

2.5. Definition of Site Quality Indicators. The gain in precision to explain the growth retardation factor as a function of a set of site descriptors was analysed in a stepwise form, increasing its complexity and costs. The first step of the analysis only used site quality information in terms of slope position of trees and its landscape orientation. The second step added soil map information based on general USDA soil classification. The last two steps, which required more effort and resources, included measured soil properties based on either soil physical (texture and bulk density) properties (step 3 ) and chemical laboratory analysis $(\mathrm{pH}$, organic matter, $\mathrm{N}$, $\mathrm{P}, \mathrm{K}$ ) in step 4 (Table 3 ).

The costs of gathering these data were relatively cheap for the first two indicators where it was only needed a field technician to measure the site locations using a GPS and later relate that information with available GIS maps. The last two site indicators (soil physical and chemical properties) were quite expensive because they required detailed analysis from a reliable laboratory. Based on the experience from this study it can be approximately estimated the price per sample of 10 (if available maps), 15 and 25\$, respectively. 


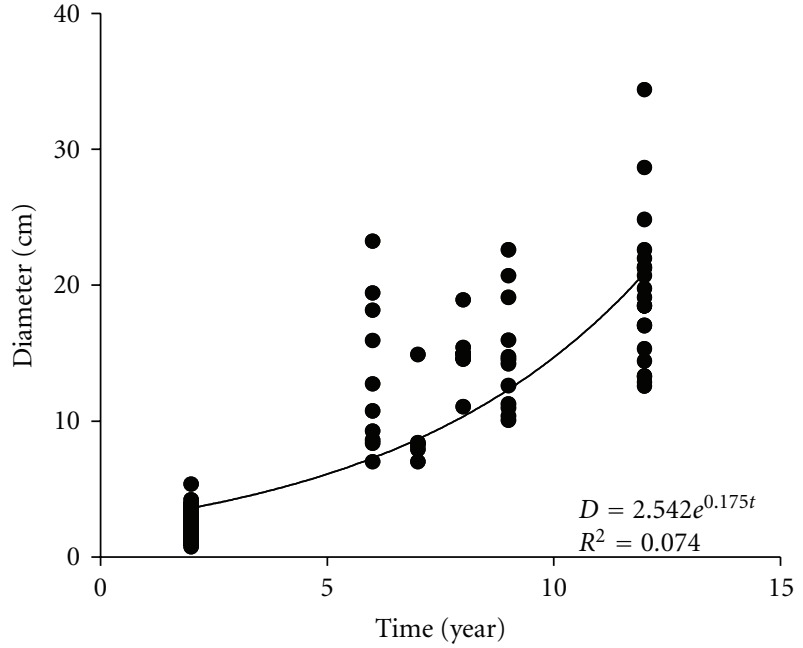

(a) Shorea contorta

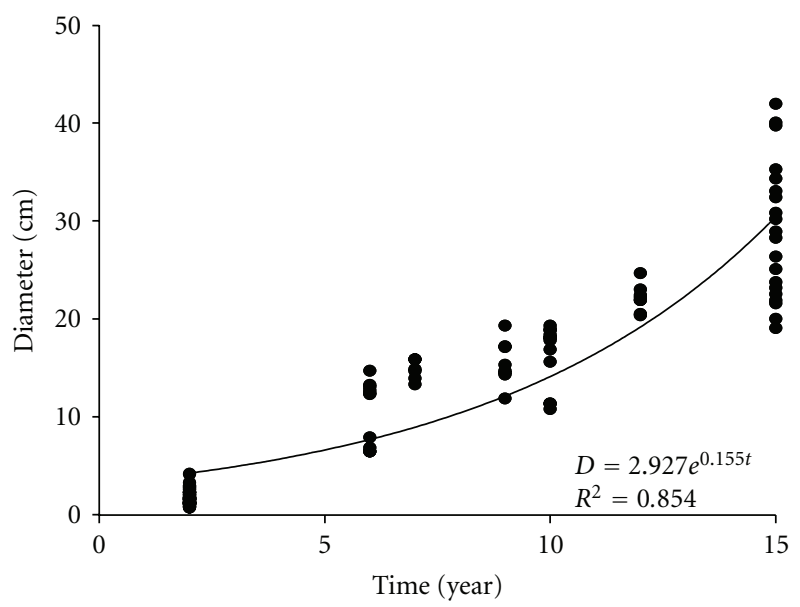

(c) Pterocarpus indicus

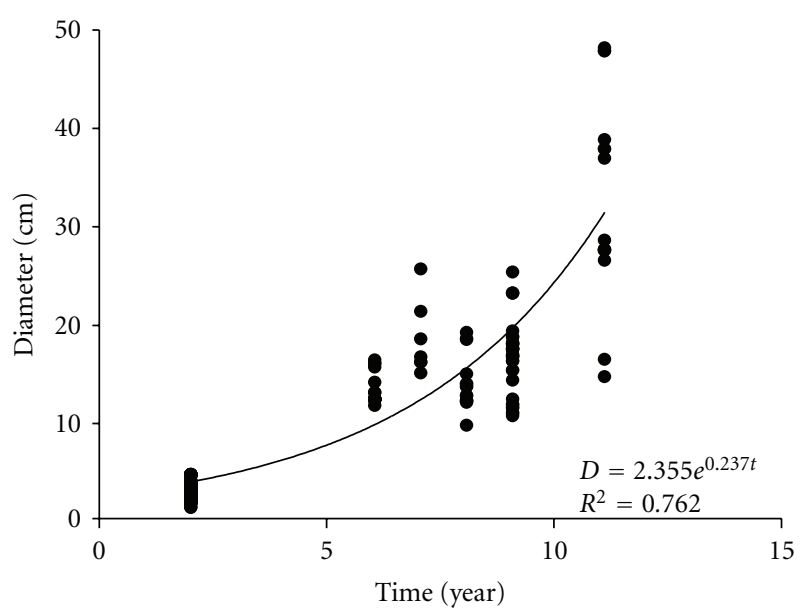

(e) Draontomelon dao

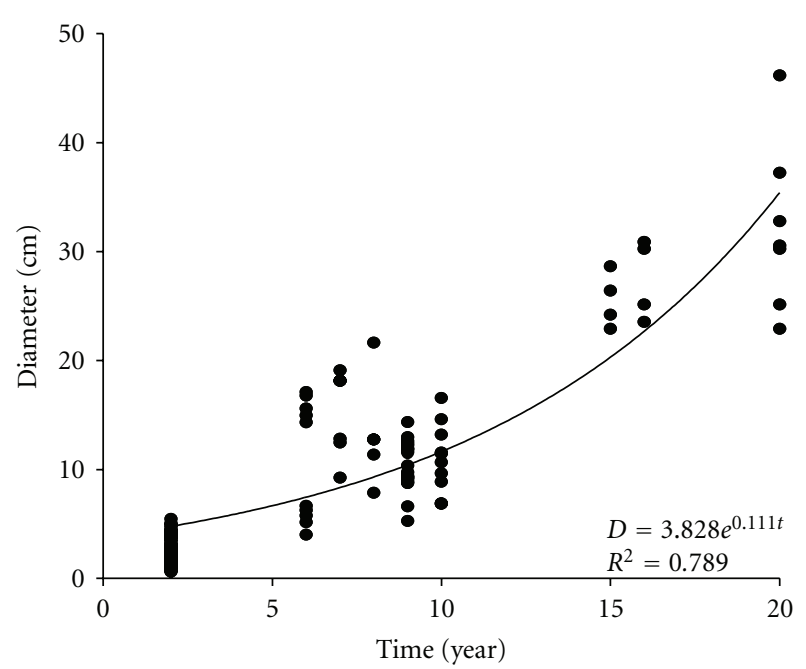

(b) Vitex parviflora

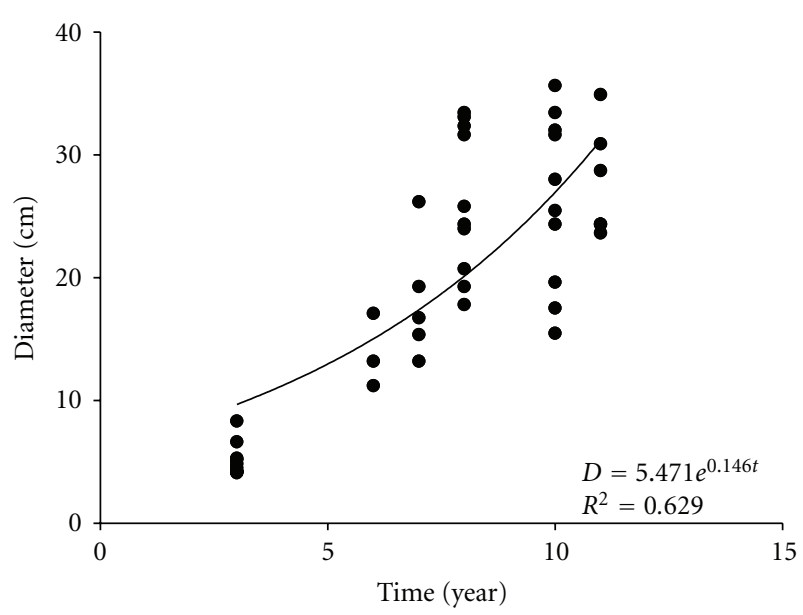

(d) Artocarpus heterophyllus

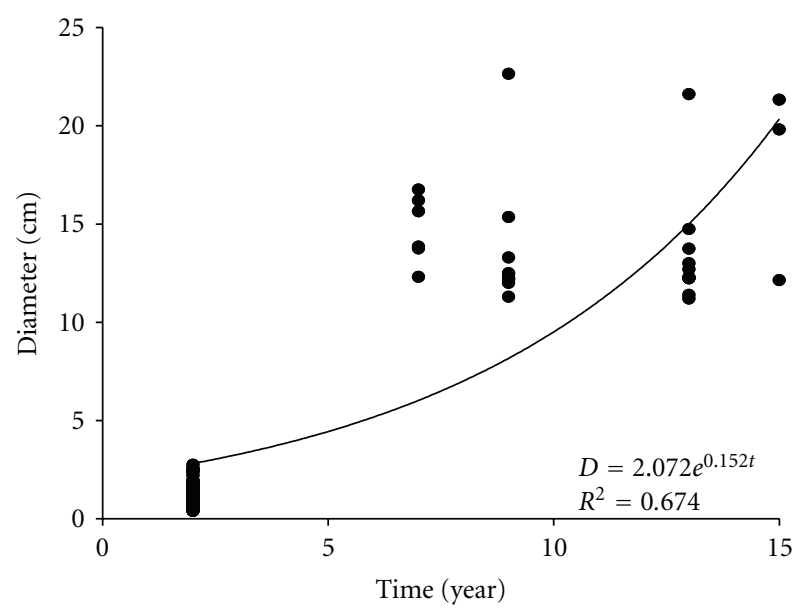

(f) Afzelia rhomboidea

FIGURE 2: Reference growth functions for six native tree species. 


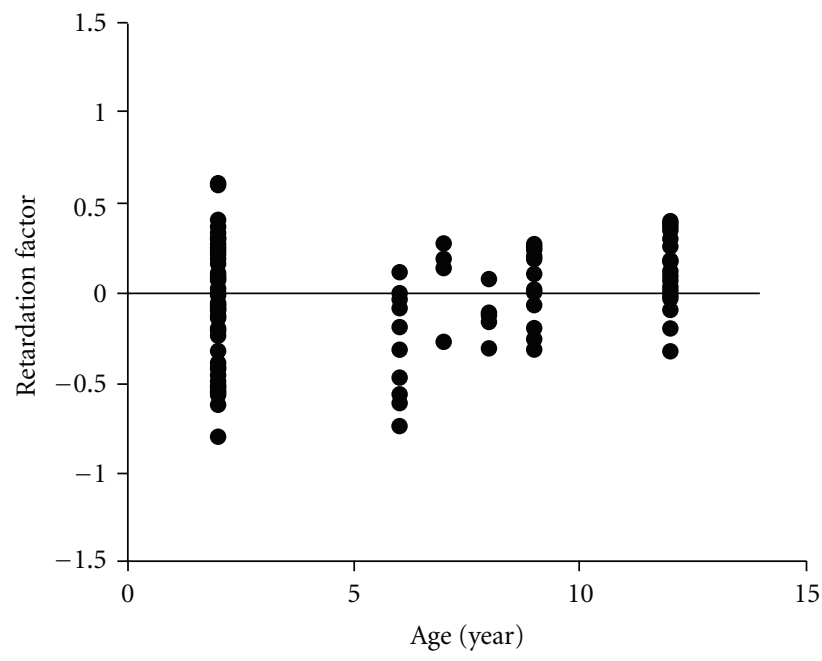

(a) Shorea contorta

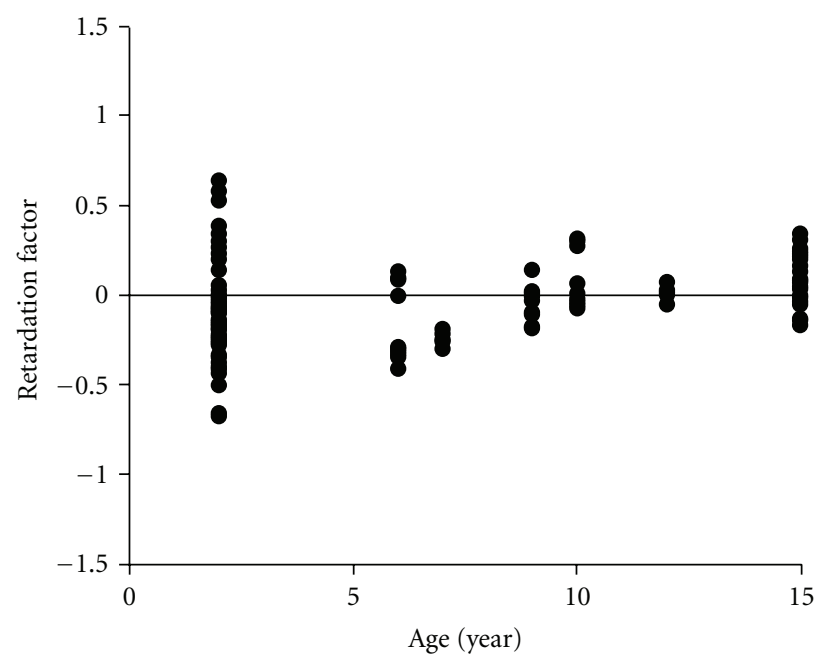

(c) Pterocarpus indicus

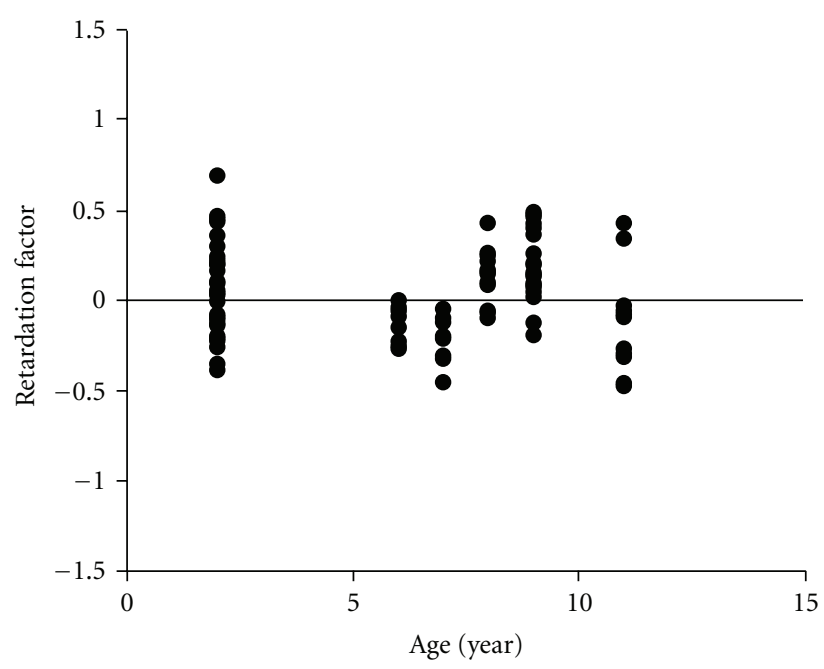

(e) Draontomelon dao

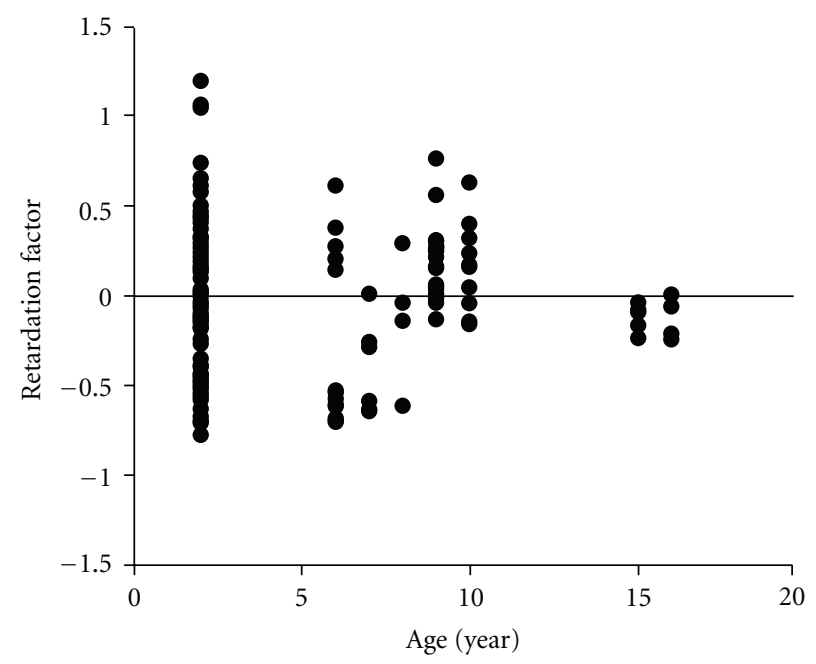

(b) Vitex parviflora

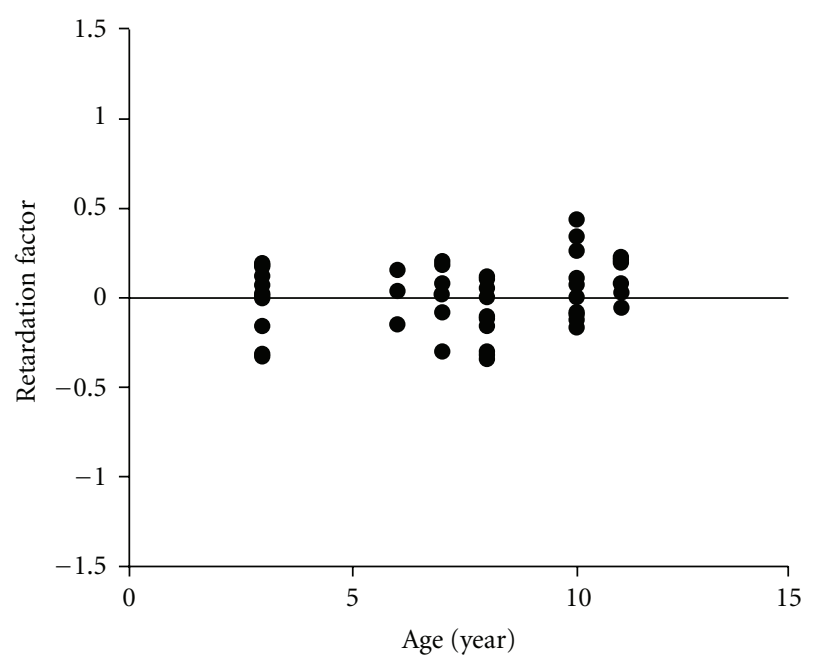

(d) Artocarpus heterophyllus

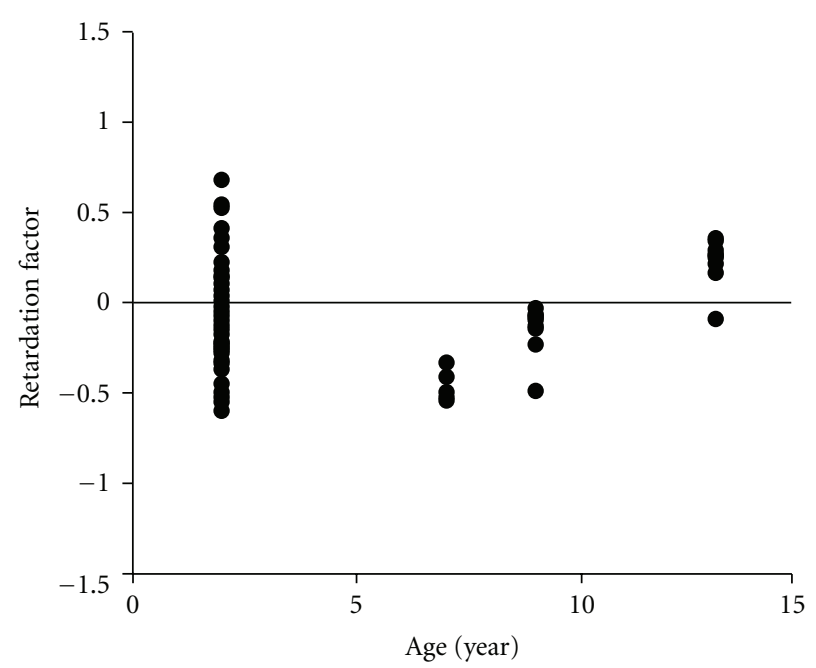

(f) Afzelia rhomboidea

FIgURE 3: Growth Retardation Factor for six native tree species. 
TABLE 3: Set of site quality indicators used in four (additive) steps of analysis.

\begin{tabular}{lll}
\hline Site Indicator & Parameter & Unit/Classification \\
\hline (1) Landscape position & Orientation & 1-N, 2-NE, 3-E, 4-SE, 5-S, 6-SW, 7-W, 8-NW \\
& Slope position & 1-Summit, 2-Upper, 3-Lower, 4-Bottom \\
\hline (2) Soil Type & Soil class & Based on USDA \\
\hline & Sand & Content of sand (\%) \\
(3) Soil physical properties & Silt & Content of silt $(\%)$ \\
& Bulk density & Bulk density $\left(\mathrm{g} / \mathrm{cm}^{3}\right)$ \\
\hline & $\mathrm{pH}$ & Soil pH using $1: 1 \mathrm{soil} \mathrm{water} \mathrm{ratio}$ \\
& Organic matter & Content organic matter $(\%)$ \\
(4) Soil chemical properties & Nitrogen & Total $N(\mathrm{mg} / \mathrm{kg})$ \\
& Phosphorus & Extractable- $P(\mathrm{me} / \mathrm{kg})$ \\
& Potassium & Exchangeable- $K(\mathrm{me} / \mathrm{kg})$
\end{tabular}

TABle 4: Tree distribution by planting niches and designs of native trees measured in Manlawaan, Leyte.

\begin{tabular}{lcccc}
\hline & Intercrop & Boundary & Scatter & Block \\
\hline Annual Crop & 106 & 56 & - & - \\
Perennial Crop & - & 104 & 153 & - \\
Grassland & - & - & 102 & 76 \\
Home garden & - & - & 77 & - \\
\hline
\end{tabular}

This information was used to evaluate the costs of obtaining various site indicators to the expected gain in predictive power of tree performance.

\section{Results}

Four different planting niches were found across the agricultural landscape: in or around annual cropping land, perennial cropping land, grassland, and home gardens. Identified farmers' tree planting designs were as follows: boundary, block, hedgerow intercropping, and scattered (Table 4). Trees found on farmers' fields were planted in association with other perennial crops (i.e., coconut plantations) or in open grassland areas commonly perceived as fallow lands, while trees intercropped with annual food crops were practiced by few farmers and always in low densities.

Soils laboratory analysis provided evidence that all sites where trees were found were poor in soil organic matter, total $N$ and extractable $P$ had a weak soil structure with high silt and low clay content (Table 5). Additionally, nutrient stocks were already small on calcareous soils and the risk of further soil depletion under annual crop systems was high [20].

Reference growth functions for each species revealed that expected stem diameter reached 30 centimetres on average at the age of fifteen years for all species (Figure 2). Substantial variation around this expected growth curve revealed that the reported age accounts for 63 to $85 \%$ of the observed variation in size, suggesting that trees do differ in their growth performance according to "site" properties and management factors.

Based on above growth references functions, the Growth Retardation Factor was calculated for every observed tree

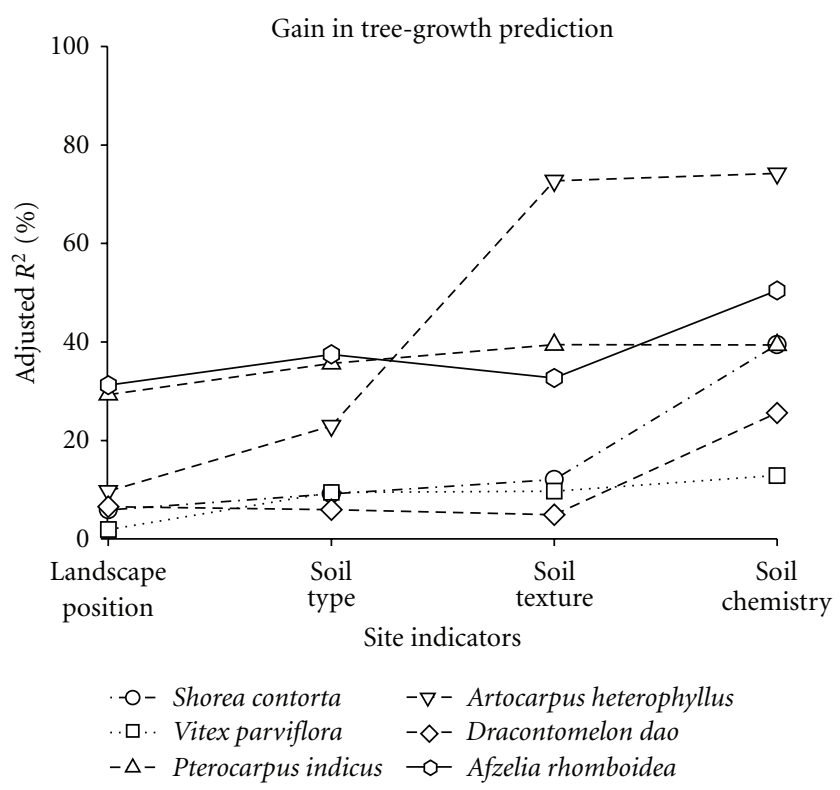

Figure 4: Stepwise gain in treegrowth prediction based on a set of simple site indicator.

(Figure 3). Negative values of GRF indicated below-average tree performance. In general, similar symmetrical distributions were found for all ages, although for bigger trees the distribution for the retardation factor was in general within the range of \pm 0.5 . For younger trees this range was expanded to \pm 1 . This suggests that the growth variation among young trees is much higher than for older ones. This may be linked to lack of precision in recorded tree age, variation in tree size at planting, and, or selective survival of only the better performing trees.

Stepwise multiple regression analysis was used to account for the variation (adjusted $R^{2}$ ) of the Growth Retardation Factor. Initially each site indicator was included into the model one by one to evaluate the influence of each indicator individually. Afterwards, all possible combinations of site indicators were analyzed together to identify the possible relationships among parameters. A Spearman Rank Order 
TABLE 5: Soil physical and chemical analysis from farmers' cooperators sites.

\begin{tabular}{|c|c|c|c|c|c|c|c|c|c|}
\hline Site & $\mathrm{pH}$ & OM (\%) & Total $N\left(\mathrm{~g} \cdot \mathrm{kg}^{-1}\right)$ & Extr- $P\left(\mathrm{me} \cdot \mathrm{kg}^{-1}\right)$ & Exch- $K\left(\mathrm{me} \cdot \mathrm{kg}^{-1}\right)$ & Bulk density $\left(\mathrm{g} \cdot \mathrm{cm}^{-3}\right)$ & Sand (\%) & Silt (\%) & Soil Class \\
\hline 1 & 7.9 & 1.7 & 0.11 & 1.9 & 86.5 & 1.49 & 9.6 & 49.3 & Inceptisols \\
\hline 2 & 8.0 & 1.1 & 0.13 & 5.1 & 147.1 & 1.49 & 32.6 & 33.9 & Inceptisols \\
\hline 3 & 7.8 & 2.4 & 0.24 & 6.0 & 145.4 & 1.52 & 20.6 & 39.6 & Entisols \\
\hline 4 & 7.8 & 2.3 & 0.27 & 2.1 & 59.8 & 1.71 & 13.6 & 39.8 & Entisols \\
\hline 5 & 7.8 & 2.2 & 0.14 & 6.7 & 349.0 & 1.45 & 19.2 & 42.2 & Inceptisols \\
\hline 6 & 7.9 & 1.8 & 0.16 & 1.1 & 120.6 & 1.49 & 9.6 & 43.3 & Inceptisols \\
\hline 7 & 7.5 & 2.7 & 0.25 & 2.5 & 107.7 & 1.71 & 9.3 & 35.2 & Entisols \\
\hline 8 & 7.9 & 2.5 & 0.29 & 3.3 & 91.5 & 1.49 & 20.0 & 40.7 & Inceptisols \\
\hline 9 & 7.5 & 2.8 & 0.26 & 1.3 & 101.1 & 1.45 & 6.9 & 30.1 & Entisols \\
\hline 10 & 8.0 & 1.3 & 0.11 & 1.8 & 95.0 & 1.71 & 17.0 & 35.6 & Inceptisols \\
\hline 11 & 8.0 & 2.9 & 0.23 & 7.8 & 167.4 & 1.49 & 11.0 & 35.1 & Inceptisols \\
\hline 12 & 8.0 & 2.6 & 0.26 & 3.9 & 63.6 & 1.45 & 49.7 & 28.1 & Inceptisols \\
\hline 13 & 8.0 & 1.4 & 0.16 & 1.5 & 68.3 & 1.71 & 10.2 & 41.2 & Entisols \\
\hline 14 & 8.1 & 1.2 & 0.17 & 2.2 & 126.0 & 1.73 & 10.3 & 42.2 & Inceptisols \\
\hline 15 & 7.9 & 1.7 & 0.13 & 2.1 & 77.8 & 1.45 & 6.2 & 41.6 & Entisols \\
\hline 16 & 7.9 & 2.9 & 0.21 & 2.4 & 109.9 & 1.49 & 12.7 & 39.1 & Inceptisols \\
\hline Mean & 7.9 & 2.1 & 0.13 & 3.2 & 119.8 & 1.55 & 16.2 & 38.6 & - \\
\hline SD & 0.2 & 0.6 & 0.03 & 2.1 & 68.6 & 0.11 & 11.2 & 5.3 & - \\
\hline
\end{tabular}

analysis was used for correlation analysis between indicators for which a relationship was apparent by visual inspection of the data.

Overall, regression analysis indicated that selected site quality indicators had different power of prediction explaining tree growth performance depending on the tree species. For instance all possible combinations of site indicators could account for $13 \%-74 \%$ of variation in tree performance (Table 6). However results clearly show that landscape position and soil chemical properties stood out as the strongest site indicators explaining tree growth performance for all species. In general, the combination of these two indicators also stood out as the most meaningful arrangement. No significant improvements were found in the gain of power of prediction with the addition of more than two site indicators into the model.

Individual soil chemical parameters contributed to understanding of site quality especially for Shorea contorta and Dracontomelon dao. For example, for Shorea contorta the first three site indicators explained less than $10 \%$ of the variation and only when "soil chemistry" was included in the model the gain of explained variation reached up to $40 \%$ (Figure 4). Artocarpus heterophyllus was the species with the highest part of variation accounted for $74.2 \%$ and Vitex parviflora was the tree species with the lowest explained variation which only reached $12.9 \%$. The effect of "landscape position" on Pterocarpus indicus was very high (29.3\%) but the rest of site indicators did not add much more information. Dracontomelon dao also had a low fraction of variation accounted for (25.6\%), mostly linked to "soil chemical" properties. In summary, these results suggest that some site quality conditions could explain a considerable part of variation in growth performance for some tree species but not for others.
A negative gain in predictive power was registered for Afzelia rhomboidea when soil texture was included in the analysis. Correlations among variables need to be taken into account to understand such effects. Results from a Spearman correlation analysis for Afzelia rhomboidea revealed that in fact there is a significant correlation between Bulk Density and Soil Classification (Table 7).

\section{Discussion}

Agroforestry practices come in many forms but have traditionally been categorized into two groups, those that are sequential, such as fallows, and those that are simultaneous, such as alley cropping [21]. However, agroforestry practices should be seen as stages in the development of an agroecosystem such that the increasing interaction of trees into landuse systems could be seen as the passage towards a mature agroforest of increasing ecological integrity [22]. In this way, with increasing scale, the integration of various agroforestry practices into the landscape is like the formation of a complex mosaic of patches in an ecosystem, each of which is composed of many niches. These niches are occupied by different organisms, making the system ecologically stable and biological diverse [8]. Thus, farmers can start to enrich their agroecosystems by progressively integrating trees in their farms resources.

In Leyte, planted trees are becoming increasingly important components of the landscape and land use systems as a strategy to recover degraded areas, maximize land resources, and provide higher returns to the farmers [23]. Study results also confirms that many farmers living on already deforested areas and with appropriate land resources spontaneously plant and manage timber trees on their farms. A variety 
TABLE 6: Stepwise multiple regressions analysis to explain growth performance in relation to site indicators.

\begin{tabular}{|c|c|c|c|c|c|c|c|c|c|}
\hline \multicolumn{4}{|c|}{ Site Indicators } & \multicolumn{6}{|c|}{ Adjusted $R^{2}(\%)$} \\
\hline $\begin{array}{l}\text { Landscape } \\
\text { Position }\end{array}$ & Soil Type & Soil Texture & Soil Chemistry & S. contorta & V. parvifora & P. indicus & A. heterophyllus & D. dao & A. rhomboidea \\
\hline \multirow[t]{4}{*}{$\mathrm{X}$} & & & & 5.9 & 1.9 & 29.3 & 9.7 & 6.6 & 31.3 \\
\hline & $\mathrm{X}$ & & & 3.6 & 4.7 & 24.5 & 9.7 & 2.7 & 11.3 \\
\hline & & $\mathrm{X}$ & & 9.5 & 2.3 & 7.4 & 46.1 & 1.5 & 3.5 \\
\hline & & & $\mathrm{X}$ & 30.5 & 9.7 & 6.5 & 71.8 & 18.1 & 26.4 \\
\hline $\mathrm{X}$ & $\mathrm{X}$ & & & 9.2 & 9.5 & 35.7 & 23.0 & 6.0 & 37.5 \\
\hline $\mathrm{X}$ & & $\mathrm{X}$ & & 11.7 & 2.9 & 36.8 & 72.7 & 5.2 & 35.5 \\
\hline \multirow[t]{4}{*}{$\mathrm{X}$} & & & $\mathrm{X}$ & 33.2 & 14.0 & 38.0 & 75.0 & 22.3 & 50.0 \\
\hline & $\mathrm{X}$ & $\mathrm{X}$ & & 10.9 & 5.2 & 23.8 & 62.7 & 9.4 & 8.5 \\
\hline & $\mathrm{X}$ & & $\mathrm{X}$ & 32.0 & 13.1 & 24.6 & 75.7 & 20.3 & 33.9 \\
\hline & & $\mathrm{X}$ & $\mathrm{X}$ & 38.6 & 8.7 & 16.4 & 71.0 & 20.9 & 24.6 \\
\hline $\mathrm{X}$ & $\mathrm{X}$ & $\mathrm{X}$ & & 12.1 & 9.7 & 39.4 & 72.7 & 4.9 & 32.7 \\
\hline $\mathrm{X}$ & $\mathrm{X}$ & & $\mathrm{X}$ & 33.2 & 13.8 & 37.6 & 70.0 & 21.8 & 44.8 \\
\hline \multirow[t]{2}{*}{$X$} & & $X$ & $\mathrm{X}$ & 39.8 & 13.3 & 40.0 & 75.6 & 26.3 & 48.0 \\
\hline & $X$ & X & $\mathrm{X}$ & 38.7 & 12.3 & 42.1 & 75.6 & 22.9 & 32.7 \\
\hline$X$ & $X$ & $X$ & $\mathrm{X}$ & 39.5 & 12.9 & 39.4 & 74.2 & 25.6 & 50.5 \\
\hline
\end{tabular}

TABLE 7: Results from Spearman correlation analysis for Afzelia rhomboidea.

\begin{tabular}{|c|c|c|c|c|c|c|c|c|c|c|c|}
\hline & Aspect & Slope & Soil Class & Bulk Density & Sand & Silt & $\mathrm{pH}$ & $\mathrm{OM}$ & $N$ & $P$ & $K$ \\
\hline Aspect & 1 & & & & & & & & & & \\
\hline Slope & -0.23 & 1 & & & & & & & & & \\
\hline \multicolumn{12}{|l|}{ Soil } \\
\hline Class & 0.42 & -0.19 & 1 & & & & & & & & \\
\hline \multicolumn{12}{|l|}{ Bulk } \\
\hline Density & 0.38 & -0.44 & 0.91 & 1 & & & & & & & \\
\hline Sand & -0.31 & 0.39 & -0.42 & -0.77 & 1 & & & & & & \\
\hline Silt & -0.33 & 0.04 & -0.17 & 0.19 & -0.53 & 1 & & & & & \\
\hline $\mathrm{pH}$ & -0.26 & 0.35 & -0.32 & -0.12 & 0.04 & 0.51 & 1 & & & & \\
\hline $\mathrm{OM}$ & -0.23 & 0.08 & -0.05 & -0.08 & 0.15 & -0.27 & -0.50 & 1 & & & \\
\hline$N$ & -0.08 & 0.25 & -0.08 & -0.19 & 0.26 & -0.21 & -0.06 & 0.75 & 1 & & \\
\hline$P$ & -0.15 & 0.44 & -0.19 & -0.40 & 0.54 & 0.00 & 0.48 & -0.20 & 0.07 & 1 & \\
\hline K & 0.17 & -0.08 & 0.05 & 0.30 & 0.05 & -0.06 & -0.22 & -0.04 & 0.01 & 0.36 & 1 \\
\hline
\end{tabular}

of pioneer and premium native species as Shorea contorta, Pterocarpus indicus, and Vitex parviflora were frequently found on farmers sites in Tabango. This contradicts the common belief among foresters and extensionists in the Philippines [24] that farmer are only interested in fastgrowing exotic trees. However, the fact that most of the native trees found on farmers' fields were not planted in association with annual food crops is an evidence that farmers are still confronted with the dilemma of whether to integrate or segregate agroforestry systems. Probably, simultaneous agroforestry systems with native trees species are not yet a wide practice among upland farmers in the Philippines because it is not yet demonstrated that it provides a superior land use in terms of feasibility, financial profitability, and food security.

The ways and places where farmers plant trees were classified into several major systems based on the types of land on which introduced trees were found and the planting systems undertaken. These results in defining groups of practices which share important ecological and managerial characteristics are in line with classifications in standard agroforestry text books [19, 25, 26].

Reference growth functions for each native species revealed that expected stem diameter reached 30 centimetres on average at the age of fifteen years for all species. This is a reasonable growth rate for medium-term timber trees and very similar to other exotic species as Swietenia macrophyla that are widely spread in the Philippines [27]. There is a common belief that farm forestry needs to involve short rotations. For example, according to Macandog et al. [28], farmers usually harvest short-rotation trees at ages between 4 to 8 years, with a preferred age of 7 years, when trees attain $20 \mathrm{~cm}$ dbh or have an average yield of 56 board feet. The popularity of exotic species with long rotation periods, such 
as Mahogany, demonstrates that farmers are willing to wait longer than what it is commonly assumed if the quality of the final product is higher.

Native trees species are commonly considered by farmers and foresters as slow growing trees, but field observations proved that in fact some of these species grow at least as fast as some exotics [14]. Therefore the domestication of native trees is dealing with an imperfect knowledge base, since these species have often been virtually overlooked by science, and are little known commercially, except in their local area. However, it is now recognized by the scientific community that the bias to native trees improvements needs to be readdressed by the development of novel approaches that take into consideration the requirements of small-scale, resource poor farmers and their farming systems. Given that improvement is as much a social and political challenge as a biological one, it will only be through experimental implementation of a range of approaches that methods and strategies will progress $[8,29]$.

The poor soil conditions encountered in the study area are probably due to inherent soil properties of calcareous soils with low organic matter content, in interaction with the effects of long-term continuous cultivation. In these site conditions, farmers have already started with the integration of trees into their farming systems as a way to improve their resources and conditions. These circumstances thus provide valuable information for assessing the suitability of some commonly used native tree species under different agroforestry systems and soil types.

Regression analysis results indicate that trees do obviously differ in their growth performance depending on the "site" properties where they are grown but direct relationship between site characteristics and tree growth were difficult to obtain, despite the large variation in the age and growing performance from place to place. Selected site quality indicators have different power of prediction explaining tree growth performance depending on the tree species. However results clearly show that landscape position and soil chemical properties stood out as the strongest site indicators explaining tree growth performance for all species. Nevertheless, the high variation of tree performance that could not be explained by the biophysical site indicators implicates that farmers take considerable risk in planting trees on the basis of current "scientific" knowledge.

If results are evaluated from a cost-benefit of modified choice based on better (and more expensive) information, some suggestions can be made. In general, site quality indicators could only account on average $40 \%$ of tree variation, and its estimated cost is around $50 \$$ per site sampled. Then, is it really worth it to expend that amount for the expected gain of information? The answer is a clear no from the farmer point of view, and a partial yes from the researcher perspective. The integration of more specific site quality information with the available general spatial information should be the next step of the approach. Despite the low power of tree growth prediction with the selected site quality indicators, the methodology can be considered an important improvement from the past standard GIS procedures which have attended to produce "suitability maps" based on very little information relevant to the particular species" growth. Probably, the complement of "site characteristics" is "management", and the low determination of tree growth by site properties may in fact be good news for the farmers.

\section{Acknowledgments}

This paper was conducted within the framework of the Smallholder Agroforestry Options on Degraded Soils (SAFODS), EU funded project (No. ICA4-CT-2001-10092), in close collaboration between the Forestry Department from University of Cordoba (Spain) and the World Agroforestry Centre (ICRAF).

\section{References}

[1] D. P. Garrity and P. C. Agustin, "Historical land use evolution in a tropical acid upland agroecosystem," Agriculture, Ecosystems and Environment, vol. 53, no. 1, pp. 83-95, 1995.

[2] M. Bertomeu, Smallholder Timber Production on Sloping Lands in the Philippines: A Systems Approach, World Agroforestry Centre, Southeast Asia Regional Research Programme, Los Baños, Philippines, 2004.

[3] PCARRD, The Philippines Recommends for Reforestation, Philippines Recommendations Series no. 49-A, Philippine Council for Agriculture, Forestry and Natural Resources Research and Development, Los Baños, Philippines, 1992.

[4] S. J. Scherr, "Meeting household needs: farmer tree-growing strategies in western Kenya," in Farms, Trees \& Farmers: Responses to Agricultural Intensification, J. E. M. Arnold and P. A. Dewees, Eds., pp. 141-173, Earthscan, London, UK, 1997.

[5] B. Lusiana and M. van Noordwijk, "Tree-site matching analysis in Indonesia and the Philippines," in Smallholder Agroforestry Options on Degraded Soils, M. van Noordwijk and T. O'Connor, Eds., pp. 17-21, World Agroforestry Centre, Bogor, Indonesia, 2006.

[6] W. Wahyunto, S. Rintung, W. Wahdini, and F. Agus, "Alternative tree crops for reconstruction of the green infrastructure post-tsunami in the coastal areas of Aceh Barat District," Indonesian Journal of Agricultural Science, vol. 10, pp. 1-12, 2008.

[7] S. Harrison and J. Herbohn, Socio-Economic Evaluation of the Potential for Australian Tree Species in the Philippines, Australian Centre for International Agricultural Research, Canberra, Australia, 2000.

[8] R. R. B. Leakey and A. J. Simons, "The domestication and commercialization of indigenous trees in agroforestry for the alleviation of poverty," Agroforestry Systems, vol. 38, no. 1-3, pp. 165-176, 1998.

[9] J. M. Roshetko and D. O. Evans, Domestication of Agroforestry Trees in Southeast Asia. Forest, Farm, and Community Tree Research Reports, World Agroforestry Centre. Southeast Asia Regional Research Programme, Bogor, Indonesia, 1999.

[10] J. B. Raintree, Socioeconomic Attributes of Trees and Tree Planting Practices, Community Forestry Note no. 9, FAO, Rome, Italy, 1991.

[11] A. Young, K. Menz, P. Muraya, and C. Smith, SCUAF Version 4: A Model to Estimate Soil Changes under Agriculture, Agroforestry and Forestry, Australian Centre for International Agricultural Research, Canberra, Australia, 1998. 
[12] F. S. Martin, Using native timber trees for recovering degraded landscapes in the Philippines: social, biophysical and economic assessment of agroforestry systems practised by smallholder farmers, Ph.D. dissertation, University of Cordoba, Cordoba, Spain, 2007.

[13] A. Groestschel, R. Aquino, I. Buchholz, et al., Natural Resource Management Strategies on Leyte Island, Philippines, SLE, Berlin, Germany, 2001.

[14] F. S. Martin, R. M. Navarro-Cerrillo, R. Mulia, and M. van Noordwijk, "Allometric equations based on a fractal branching model for estimating aboveground biomass of four native tree species in the Philippines," Agroforestry Systems, vol. 78, no. 3, pp. 193-202, 2010.

[15] F. Torres, J. B. Raintree, M. V. Dalmacio, and T. Domhofer, "Agroforestry systems for smallholder upland farmers in a land reform area of the Philippines: the Tabango case study," in Man, Agriculture and the Tropical Forest: Change and Development in the Philippines Uplands, S. Fujisaka and P. Sajise, Eds., pp. 244-268, Winrock International and Institute for Agricultural Development, Bangkok, Thailand, 1986.

[16] K. Hairiah, M. van Noordwijk, B. Santoso, and M. S. Syeskfani, "Biomass production and root distribution of eight trees and their potential for hedgerow intercropping on an ultisol in southern Sumatra," Agrivita, vol. 15, pp. 54-68, 1992.

[17] M. van Noordwijk and R. Mulia, "Functional branch analysis as tool for fractal scaling above and belowground trees for their additive and non-additive properties," Ecological Modelling, vol. 149, no. 1-2, pp. 41-51, 2002.

[18] Q. M. Ketterings, R. Coe, M. van Noordwijk, Y. Ambagau', and C. A. Palm, "Reducing uncertainty in the use of allometric biomass equations for predicting above-ground tree biomass in mixed secondary forests," Forest Ecology and Management, vol. 146, no. 1-3, pp. 199-209, 2001.

[19] P. Huxley, Tropical Agroforestry, Blackwell Science, Oxford, UK, 1999.

[20] PCARRD, The Philippines Recommends for Soil Fertility Management, Philippines Recommendations Series no. 36C, Philippine Council for Agriculture, Forestry and Natural Resources Research and Development, Los Baños, Philippines, 1999.

[21] P. J. M. Cooper, R. R. B. Leakey, M. R. Rao, and L. Reynolds, "Agroforestry and the mitigation of land degradation in the humid and sub-humid tropics of Africa," Experimental Agriculture, vol. 32, no. 3, pp. 235-290, 1996.

[22] R. R. B. Leakey, "Definition of agroforestry revisited," Agroforestry Today, vol. 8, no. 1, pp. 5-7, 1996.

[23] A. Schulte, Rainforestation Farming: Option for Rural Development and Biodiversity Conservation in the Humid Tropics of Southeast Asia. A Review of Major Issues on CommunityBased Rehabilitation Silviculture and Guide to Recommended Native Tree Species for the Visayas/Philippines, Shaker, Aachen, Germany, 2002.

[24] P. N. Pasicolan, H. A. Udo de Haes, and P. E. Sajise, "Farm forestry: an alternative to government-driven reforestation in the Philippines," Forest Ecology and Management, vol. 99, no. 1-2, pp. 261-274, 1997.

[25] P. K. R. Nair, An Introduction to Agroforestry, Kluwer Academic Publishers, London, UK, 1993.

[26] A. Young, Agroforestry for Soil Management, CAB International, Wallingford, UK, 1997.

[27] F. S. Martin and M. van Noordwijk, "Trade-offs analysis for possible timber-based agroforestry scenarios using native trees in the Philippines," Agroforestry Systems, vol. 76, no. 3, pp. 555-567, 2009.
[28] D. B. Magcale-Macandog, K. Menz, P. M. Rocamora, and C. D. Predo, "Smallholder timber production and marketing: the case of Gmelina arborea in Claveria, Northern Mindanao, Philippines," International Tree Crops Journal, vol. 10, no. 1, pp. 61-78, 1999.

[29] F. L. Sinclair, "Process-based research in sustainable agricultural development: integrating social, economic and ecological perspectives," Agricultural Systems, vol. 69, no. 1-2, pp. 1-3, 2001. 

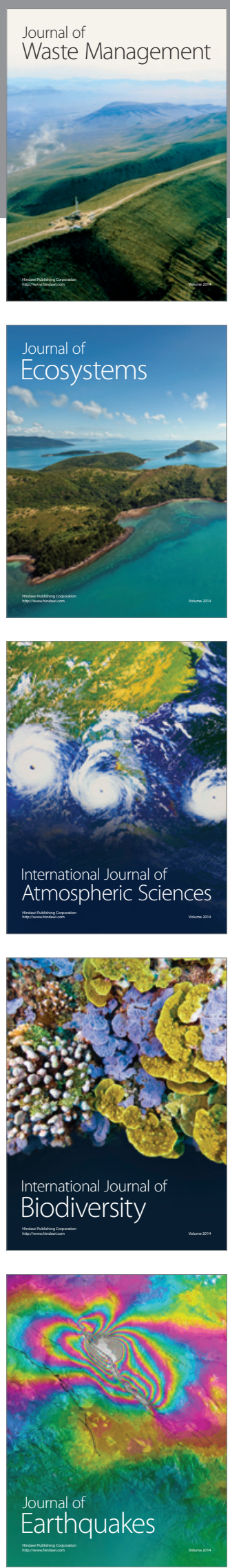
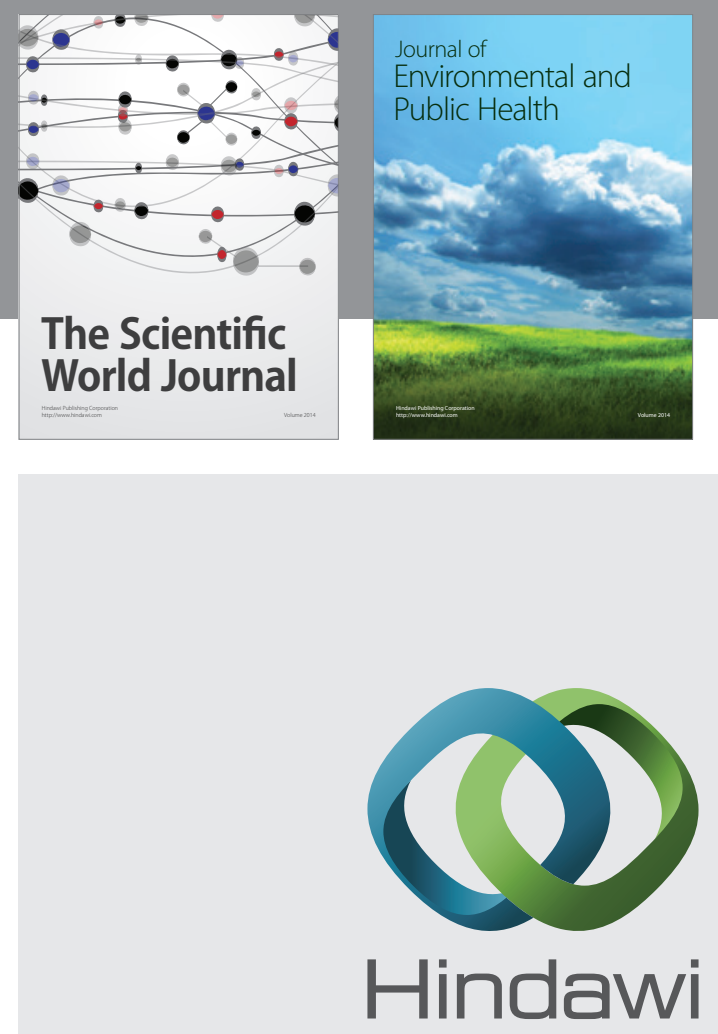

Submit your manuscripts at

http://www.hindawi.com
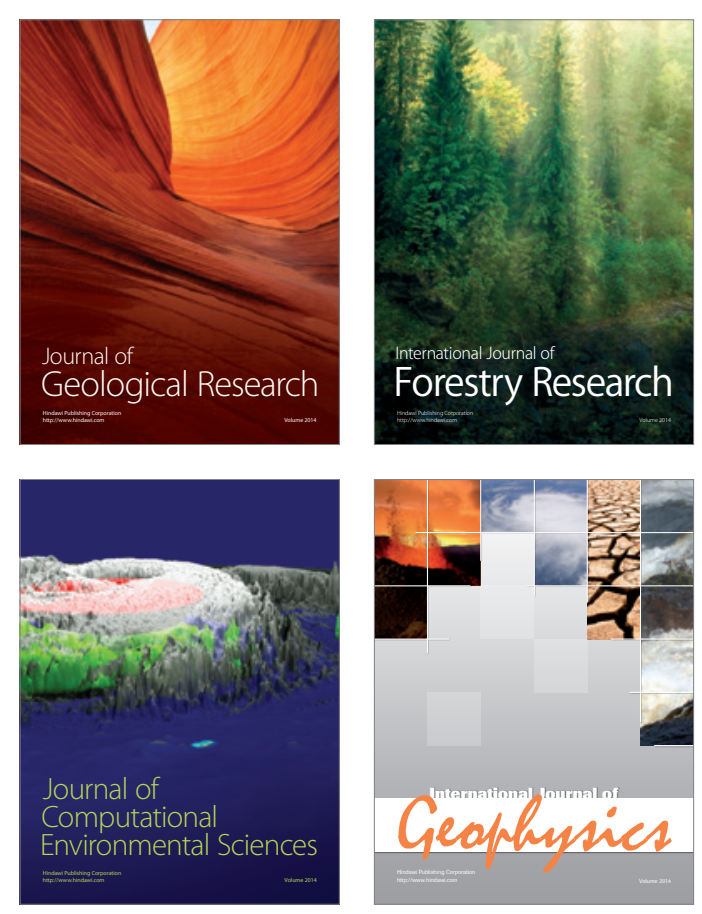
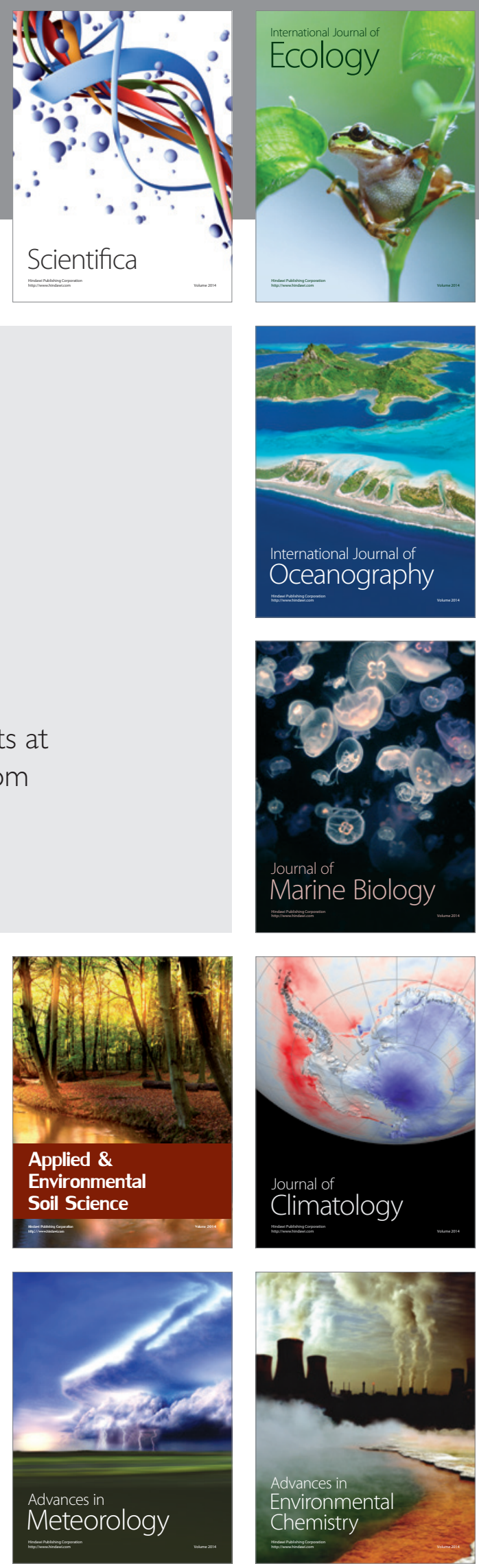